\title{
A novel analytical approach for reducing the consumption of organic solvents in the charge transfer-based spectrophotometric analysis: Application in the analysis of certain antihypertensive drugs
}

IBRAHIM A. DARWISH ${ }^{1, *}$

ASHRAF M. MAHMOUD ${ }^{1,2}$

ABDUL-RAHMAN A. AL-MAJED ${ }^{1}$

1 Department of Pharmaceutical

Chemistry, College of Pharmacy

King Saud University, P.O. Box 2457

Riyadh 11451, Saudi Arabia

${ }^{2}$ Department of Pharmaceutical Analytical Chemistry, Faculty of Pharmacy, Assiut University, Assiut 71526, Egypt

Accepted October 5, 2010

* Correspondence; e-mail: idarwish@ksu.edu.sa
The present study describes the development of a novel analytical approach that can reduce by 50 -fold the consumption of organic solvents in the charge transfer (CT)-based spectrophotometric analysis. The proposed approach employed 96-microwell assay plates for carrying out the reaction. The CT reaction between the electron-donating analyte and electron-accepting reagent was performed in microwells (200- $\mu \mathrm{L}$ of organic solvent) and the color signals were measured with a microwell-plate reader. Optimum conditions for the proposed approach were established for two antihypertensive drugs, namely ramipril (RML) and lisinopril (LSL) as model compounds for the electron-donating analytes, and 2,3-dichloro-5,6-dicyano-1,4-benzoquinone (DDQ) as a $\pi$-electron acceptor. Under the optimum conditions, Beer's law was obeyed in the concentration range of $6-100$ and $6-60 \mu \mathrm{g} \mathrm{mL}^{-1}$ for RML and LSL, respectively. The limits of detection were 0.97 and $1.10 \mu \mathrm{g} \mathrm{mL}^{-1}$ for RML and LSL, respectively. The precision of the methods was satisfactory; the values of relative standard deviations did not exceed $1.1 \%$. The proposed approach was successfully applied to the analysis of pharmaceutical dosage forms with good accuracy and precision. The results were comparable with those of the reported methods. The approach described herein is of great practical value in pharmaceutical analysis because it reduces the exposure of analysts to the toxic effects of organic solvents, lowers the analysis cost by 50 -fold, and it has a high throughput property. Although the approach was validated for RML and LSL, the same methodology could be used for any electron-donating analyte for which a CT-reaction can be performed.

Keywords: charge-transfer reaction, organic solvents, spectrophotometry, ramipril, lisinopril 
I. A. Darwish et al:: A novel analytical approach for reducing the consumption of organic solvents in the charge transfer-based spectrophotometric analysis: Application in the analysis of certain antihypertensive drugs, Acta Pharm. 60 (2010) $493-501$.

Spectrophotometry is the most widely used technique in pharmaceutical analysis because of its inherent simplicity and wide availability in quality control laboratories (1). Molecular interactions between electron-donating pharmaceutical compounds and electron acceptors are generally associated with the formation of intensely colored charge transfer (CT) complexes, which absorb radiation in the visible region. The rapid formation of these complexes leads to their widespread utility in the development of simple and convenient spectrophotometric methods for many pharmaceutical compounds (2-4). However, all the CT-based spectrophotometric methods described so far suffer from the consumption of large volumes of organic solvents. This leads to high analysis costs, and more importantly, exposure of analysts to toxic solvents.

Many studies support the positive association between the exposure to laboratory work with organic solvents and occurrence of dose-related neurotoxic symptoms (5), increased risk of some reproductive outcomes (especially preterm and posterm births) among women performing certain laboratory tasks (6), increased risk of spontaneous abortion among pregnant women $(7,8)$, and increased risk of lymphohaematopoietic cancer (leukemia and lymphomas) in men and women alike (9). Reduction of human exposure to organic solvents is one of the main objectives of hygienists, public authorities, World Health Organization, U.S. Environment Protection Agency, and U.S. Occupational Safety and Health Administration. For these reasons, investigating new alternative methodological approaches to reduce the consumption of organic solvents in charge-transfer-based spectrophotometric analysis of the therapeutically important compounds is very important.

The present study describes the development of a novel approach that can reduce by 50 -fold the consumption of organic solvents in the CT-based spectrophotometric analysis. In this approach, the reaction was carried out in 96 -microwell plates $(0.2 \mathrm{~mL}$ volume) instead of the conventional volumetric flasks (10 mL volume). Color signals were measured with a microwell-plate reader.

The approach was developed, validated, and applied to the analysis of two antihypertensive drugs: ramipril and lisinopril (Fig. 1), inhibitors of angiotensin-converting enzyme, in their pharmaceutical dosage forms.

A literature survey of CT reactions of electron-donating compounds with polyhalo-/polycyanoquinones electron acceptors has revealed that DDQ is one of the most reactive reagents, since its reaction with electron-donating analytes proceeds instantaneously (2) and yields more sensitive assays compared to other polyhaloquinones (10). For these reasons, DDQ was selected as electron acceptor in the development of the approach described herein.

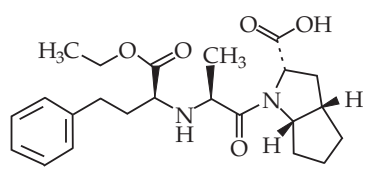

Ramipril (RML)

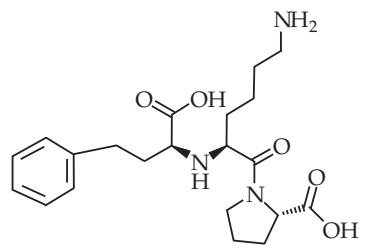

Lisinopril (LSL)

Fig. 1. Chemical structures of the investigated antihypertensive drugs. 
I. A. Darwish et al:: A novel analytical approach for reducing the consumption of organic solvents in the charge transfer-based spectrophotometric analysis: Application in the analysis of certain antihypertensive drugs, Acta Pharm. 60 (2010) $493-501$.

The electron-donating capabilities of RML (11) and LSL (12) have been demonstrated in previous reports. Since the aim of this study was to develop a new approach for reduction of the consumption of organic solvents in the CT-based spectrophotometric analysis of pharmaceutical compounds, RML and LSL were considered as model compounds.

\section{EXPERIMENTAL}

\section{Equipment}

Absorbance microwell-plate reader (ELx808IU, BioTek Instruments Inc., USA) was used for all measurements in 96-microwell plates. Microwell plates were obtained from Corning/Costar Inc. (USA). Finnpipette adjustable 8 channel-pipette was purchased from Sigma Chemical Co., USA.

\section{Chemicals and dosage forms}

Ramipril (Hoechst Orient, Cairo, Egypt) and lisinopril (Zeneca Ltd., UK) were obtained and used as working standards. DDQ solution (Merck, Germany) was prepared fresh in methanol daily. Tritace ${ }^{\circledR}$ tablets (Hoechst Orient, Egypt) are labeled to contain $2.5 \mathrm{mg}$ RML per tablet. Zestril ${ }^{\circledR}$ tablets (Zeneca Ltd., UK) are labeled to contain $20 \mathrm{mg}$ LSL and $12.5 \mathrm{mg}$ hydrochlorothiazide (HCT) per tablet.

\section{Preparation of standards and sample solutions}

Stock standard solutions. - Into a 5-mL calibrated flask, $10 \mathrm{mg}$ of each RML and LSL was accurately weighed, dissolved in $2 \mathrm{~mL}$ methanol, and made up to the volume with the same solvent. These stock solutions were diluted with methanol to obtain suitable concentrations in the linear range for each particular drug.

Sample solutions. - Twenty tablets of each formulation were weighed and finely powdered. A quantity of the powder equivalent to $20 \mathrm{mg}$ was transferred into a $10-\mathrm{mL}$ calibrated flask, dissolved in $2 \mathrm{~mL}$ methanol, swirled and sonicated for $5 \mathrm{~min}$, made up to the volume with methanol, shaken well for $15 \mathrm{~min}$, and filtered. The first portion of the filtrate was rejected, and a measured volume of the filtrate was diluted quantitatively with methanol to yield suitable concentrations in the linear range of each particular drug.

\section{General analytical procedure}

One hundred microliters of the standard or sample solution of each drug (12-200 and $12-120 \mu \mathrm{g} \mathrm{mL}^{-1}$ for RML and LSL, respectively) was transferred into wells of microwell-plates. One hundred microliters of DDQ solution $(0.5$ and $2 \%, m / V$, for RML and LSL, respectively) was added, and the reaction was allowed to proceed at room temperature $\left(25 \pm 5^{\circ} \mathrm{C}\right)$ for $15 \mathrm{~min}$. Absorbances of the resulting solutions were measured at 
I. A. Darwish et al:: A novel analytical approach for reducing the consumption of organic solvents in the charge transfer-based spectrophotometric analysis: Application in the analysis of certain antihypertensive drugs, Acta Pharm. 60 (2010) $493-501$.

$460 \mathrm{~nm}$ by the microwell-plate reader. Blank wells were treated similarly, except for 100 $\mu \mathrm{L}$ of methanol that was used instead of a sample, and the absorbances of blank wells were abstracted from those of other wells.

\section{Validation}

The following validation parameters were assessed and evaluated according to the pharmacopoeial guidelines (13).

Linearity and sensitivity. - Employing the above mentioned general analytical procedures, the calibration curves for the analysis of both RML and LSL by the proposed analytical approach were constructed by plotting the absorbances as a function of the corresponding concentrations. The regression equations for the results were derived using the least-squares method. The limits of detection $(L O D)$ and limits of quantitation $(L O Q)$ were determined using the formula: $L O D$ or $L O Q=\kappa \mathrm{SD}_{\mathrm{a}} / b$, where $\kappa=3.3$ for $L O D$ and 10 for $L O Q, \mathrm{SD}_{\mathrm{a}}$ is the standard deviation of the intercept, and $b$ is the slope.

Accuracy and precision. - Accuracy of the proposed methodology was assessed by analytical recovery studies. Recovery was determined by the standard addition method. Known amounts of each of RML and LSL were added to predetermined drug-containing dosage forms, and then determined by the recommended procedure of the proposed methodology. The mean analytical recovery was calculated as the ratio of the concentrations measured to the concentrations taken for analysis, expressed as percentages.

Precision was determined on samples of drug solutions at three concentration levels for each drug by analyzing 5 replicates of each sample as a batch in a single assay run.

\section{RESULTS AND DISCUSSION}

\section{Reaction and spectral characteristics}

The interaction of each of RML and LSL with DDQ was allowed to proceed at room temperature, and the absorption spectra of the produced chromogens were recorded. All drugs gave red colored chromogens showing absorption maxima at 460, 545, and 593 $\mathrm{nm}$. These bands were attributed to the formation of the radical anion $\mathrm{DDQ}^{-}(14)$, which was probably formed by the dissociation of an original donor-acceptor (D-A) complex:

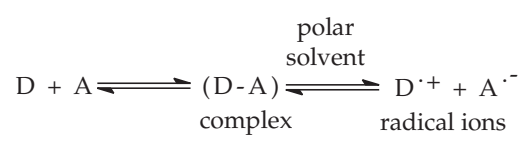

Further support to this assignment was provided by the absorption maxima with those of the DDQ radical anion produced by the iodide reduction method (15). Dissociation of the (D-A) complex was promoted by the high ionizing power of the polar solvent and the resulting peaks in the absorption spectra of drug-acceptor reaction mixtures were similar to the maxima of radical anions of the acceptors obtained by the iodide reduction method (15). 
I. A. Darwish et al:: A novel analytical approach for reducing the consumption of organic solvents in the charge transfer-based spectrophotometric analysis: Application in the analysis of certain antihypertensive drugs, Acta Pharm. 60 (2010) $493-501$.

\section{Optimization of experimental conditions}

Optimization of the experimental conditions affecting the reaction in the 96-well format was investigated by altering each reaction variable in turn while keeping the others constant. In all cases, measurements were carried out at $460 \mathrm{~nm}$, since this maximum gave the highest absorptivity and ultimately the highest analytical sensitivity. The results of variations in DDQ concentrations indicated that $100 \mu \mathrm{L}$ of 0.5 and $2 \%(\mathrm{~m} / \mathrm{V})$ were the optimum DDQ concentrations for RML and LSL, respectively, as these concentrations gave the highest absorbance. Previous studies (4) have demonstrated that the interaction of electron-donors with DDQ in polar solvents (e.g., acetonitrile and methanol) produces charge-transfer complexes with molar absorptivity values higher than those produced in non-polar solvents (e.g., chloroform). Methanol was selected for subsequent experiments because it offered high sensitivity. The optimum reaction time was determined by monitoring color development in the microwells at room temperature (25 $\pm 5{ }^{\circ} \mathrm{C}$ ). Complete color development was attained after 12 and $10 \mathrm{~min}$ for RML and LSL, respectively. The developed colors of the two drugs remained stable at room temperature for at least another $30 \mathrm{~min}$. Based on these facts, and to establish convenient general methodology, reactions in subsequent experiments were allowed to proceed for $15 \mathrm{~min}$ before measuring the color signals by the plate reader. A summary of the optimum conditions is given in Table I.

\section{Validation}

Linearity and sensitivity. - In all cases, Beer's law plots $(n=5)$ were linear with correlation coefficients in the general concentration ranges (6-100 and 6-60 $\mu \mathrm{g} \mathrm{mL}^{-1}$ for RML and LSL, respectively) of 0.9998 and 0.9997 for RML and LSL, respectively (Table II). The $L O D$ values were 0.97 and $1.10 \mu \mathrm{g} \mathrm{mL}^{-1}$ for RML and LSL, respectively. The $L O Q$ values were 2.95 and $3.32 \mu \mathrm{g} \mathrm{mL}^{-1}$ for RML and LSL, respectively (Table II).

Accuracy and precision. - The mean analytical recovery for the proposed methodology was $100.8 \pm 0.8$ and $98.8 \pm 0.8 \%$ for RML and LSL, respectively (Table III) indicating the accuracy of the proposed methodology.

Relative standard deviations (RSD) did not exceed 1.1 and $1.59 \%$ for intra- and inter-batch, respectively (Table IV), proving the high precision of the methodology for the routine application in quality control laboratories. This high level of precision was

Table I. Optimum conditions for the CT reaction of DDQ with ramipril and lisinopril

\begin{tabular}{lcc}
\hline Conditions & RML & LSL \\
\hline DDQ $(\%, m / V)$ & 0.5 & 2 \\
Solvent & Methanol & Methanol \\
Reaction time $(m i n)$ & 12 & 10 \\
Temperature $\left({ }^{\circ} \mathrm{C}\right)$ & $25 \pm 5$ & $25 \pm 5$ \\
Measuring wavelength $(\mathrm{nm})^{\mathrm{a}}$ & 460 & 460 \\
\hline
\end{tabular}

a Wavelength was determined in this study. 
I. A. Darwish et al:: A novel analytical approach for reducing the consumption of organic solvents in the charge transfer-based spectrophotometric analysis: Application in the analysis of certain antihypertensive drugs, Acta Pharm. 60 (2010) $493-501$.

Table II. Quantitative analytical parameters of the proposed analytical approach for determination of ramipril and lisinopril

\begin{tabular}{|c|c|c|c|c|c|c|}
\hline \multirow{2}{*}{ Drug } & \multirow{2}{*}{$\begin{array}{l}\text { Conc. range } \\
\left(\mu \mathrm{g} \mathrm{mL}^{-1}\right)\end{array}$} & \multicolumn{2}{|c|}{ Calibration line } & \multirow{2}{*}{$\begin{array}{c}\text { Correlation } \\
\text { coefficient }(R)\end{array}$} & \multirow{2}{*}{$\begin{array}{c}L O D^{\mathrm{a}} \\
\left(\mu \mathrm{g} \mathrm{mL}^{-1}\right)\end{array}$} & \multirow{2}{*}{$\begin{array}{c}L O Q^{\mathrm{a}} \\
\left(\mu \mathrm{g} \mathrm{mL}^{-1}\right)\end{array}$} \\
\hline & & Intercept $\pm \mathrm{SD}^{\mathrm{a}}$ & Slope $\pm S D^{b}$ & & & \\
\hline RML & $6-100$ & $-0.0330 \pm 0.00310$ & $0.0105 \pm 0.00420$ & 0.9998 & 0.97 & 2.95 \\
\hline LSL & $6-60$ & $0.01634 \pm 0.00973$ & $0.0293 \pm 0.00531$ & 0.9997 & 1.10 & 3.32 \\
\hline
\end{tabular}

attributed to the accuracy of the volumes that were concomitantly dispensed into the microwells with multi-channel pipettes $(200 \mu \mathrm{L})$.

Selectivity. - The advantage of the proposed method is that the measurements are performed in the visible region, away from the UV-absorbing interfering substances that might be co-extracted from drugs-containing dosage forms. Interference from the congenital hydrochlorothiazide (HCT) that is co-formulated with LSL in some of its dosage forms (Zestril ${ }^{\circledR}$ tablets) was studied in a ratio normally present in the dosage form (LSL:HCT = 1.6). No interference from HCT with the proposed method for LSL was found. This selectivity of the CT reaction for RML and LSL was attributed to their basic character, which allows the $\mathrm{CT}$, rather than HCT, which does not have sufficient basicity, to achieve CT reaction $\left(\mathrm{pK}_{\mathrm{a}}=7.9\right)(16)$. Further, no interference with the proposed me-

Table III. Recovery of the proposed approach for determination of RML and LSL

\begin{tabular}{cccc}
\hline \multirow{2}{*}{ Drug } & \multicolumn{2}{c}{ Concentration $\left(\mu \mathrm{g} \mathrm{mL}^{-1}\right)$} & \\
\cline { 2 - 3 } & Pre-analyzed & Added & \\
\hline RML & 50 & 40 & $100.8 \pm 0.8$ \\
LSL & 20 & 20 & $98.8 \pm 0.8$ \\
\hline
\end{tabular}

a Mean $\pm \operatorname{SD}(n=3)$.

Table IV. Precision of the proposed approach of analysis of RML and LSL

\begin{tabular}{cccc}
\hline \multirow{2}{*}{ Drug } & \multirow{2}{*}{$\begin{array}{c}\text { Concentration level of } \\
\text { model solution }\left(\mu \mathrm{mL}^{-1}\right)\end{array}$} & \multicolumn{2}{c}{$\mathrm{RSD}(\%)^{\mathrm{a}}$} \\
\cline { 3 - 4 } & 10 & Intra-batch & Inter-batch \\
\hline RML & 50 & 1.0 & 1.3 \\
& 100 & 0.8 & 1.0 \\
\multirow{2}{*}{ LSL } & 6 & 0.6 & 1.6 \\
& 30 & 0.8 & 1.5 \\
& 60 & 1.1 & 1.3 \\
\hline
\end{tabular}

a $n=5$ 
I. A. Darwish et al:: A novel analytical approach for reducing the consumption of organic solvents in the charge transfer-based spectrophotometric analysis: Application in the analysis of certain antihypertensive drugs, Acta Pharm. 60 (2010) $493-501$.

Table V. Analysis of RML and LSL in their dosage forms by the proposed and reported methods

\begin{tabular}{|c|c|c|c|c|}
\hline \multirow{2}{*}{ Dosage form } & \multicolumn{2}{|c|}{ Amounts found (mg per tablet) ${ }^{\mathrm{a}}$} & \multirow{2}{*}{$t$-test ${ }^{b}$} & \multirow{2}{*}{$F$-test } \\
\hline & Proposed method & Reported method $(12,13)$ & & \\
\hline $\begin{array}{c}\text { Tritace }^{\circledR} \text { tablets } \\
\text { (2.5 mg RML per tablet) }\end{array}$ & $2.52 \pm 0.04$ & $2.53 \pm 0.04$ & 0.55 & 1.37 \\
\hline $\begin{array}{c}\text { Zestril }^{\circledR} \text { tablets } \\
\text { (20 mg LSL per tablet) }\end{array}$ & $20.10 \pm 0.26$ & $19.7 \pm 0.34$ & 1.95 & 1.73 \\
\hline
\end{tabular}

a Mean $\pm \operatorname{SD}(n=6)$.

b The tabulated values of $t$ - and $F$ - at $95 \%$ confidence limit $(n=6)$ are 2.78 and 6.39 , resp.

thod was observed from the excipients, as indicated by good recovery (Table III). The absence of interference from these excipients was attributed to the extraction with an organic solvent prior to the analysis.

\section{Analysis of dosage forms}

Commercially available pharmaceutical dosage forms of the investigated compounds were subjected to the analysis by the proposed and reported spectrophotometric methods for RML (12) and LSL (13), and the obtained results were then statistically compared. The amounts of RML and LSL measured by the proposed procedure were comparable with those obtained by the reported methods. In the $t$ - and F-tests, no significant differences were found between the calculated and theoretical values of both the proposed and reported methods at $95 \%$ confidence level. This indicated comparable accuracy and precision in the analysis by the proposed and reported methods.

\section{CONCLUSIONS}

The present study described the development and validation of a novel analytical approach for reducing by 50 -fold the consumption of organic solvents in the spectrophotometric analysis based on CT reactions. In this approach, the reaction was carried out in 96-microwell plates (200- $\mu \mathrm{L}$ reaction volume) instead of the conventional volumetric flasks. The color signals were measured by a microwell-plate reader instead of a conventional spectrophotometer. The analytical approach described herein has the following advantages:

(i) Reduction in the consumption of organic solvents in the CT-based spectrophotometric analysis and accordingly reduction in the exposure of analysts to the toxic effects of organic solvents.

(ii) Reduction by 50 -fold in analysis costs, which can be reflected on the price of finished dosage forms, thus reducing the expenses for medications.

(iii) Provision of a high throughput analytical methodology that can facilitate the processing of a large number of samples in a relatively short time. This property was 
I. A. Darwish et al.: A novel analytical approach for reducing the consumption of organic solvents in the charge transfer-based spectrophotometric analysis: Application in the analysis of certain antihypertensive drugs, Acta Pharm. 60 (2010) $493-501$.

attributed to the use of multi-channel pipettes for efficient dispensing of the solutions, carrying out the analytical reaction in 96-well plates (as reaction vessels), and measuring the color signals in the 96 wells at 230 seconds by the plate reader.

(iv) Although the approach was developed and validated for the analysis ramipril and lisinopril, it is also anticipated that the same methodology could be used for practically any analyte that can exhibit electron-donating capability.

Acknowledgments. - The authors thank the Research Center of the College of Pharmacy, King Saud University, for funding this study (grant No. C.P.R.C. 225).

\section{REFERENCES}

1. S. Görög, Ultraviolet-Visible Spectrophotometry in Pharmaceutical Analysis, CRC Press, New York 1994.

2. I. A. Darwish, Analytical study for the charge transfer complexes of losartan potassium, Anal. Chim. Acta 549 (2005) 212-220; DOI: 10.1016/j.aca.2005.06.023.

3. I. A. Darwish and I. H. Refaat, Spectrophotometric analysis of selective serotonin reuptake inhibitors based on formation of charge-transfer complexes with tetracyanoquinondimethane and chloranilic acid, J. AOAC Int. 89 (2006) 326-333; DOI: 10.5555/jaoi.89.2.326.

4. G. A. Saleh, H. F. Askal, I. A. Darwish and A. A. El-Shorbagi, Spectroscopic analytical study for the charge-transfer complexation of certain cephalosporins with chloranilic acid, Anal. Sci. 19 (2003) 281-287; DOI: 10.1136/oem.44.5.292.

5. A. T. Fidler, E. L. Baker and R. E. Letz, Neurobehavioural effects of occupational exposure to organic solvents among construction painters, Br. J. Ind. Med. 44 (1987) 292-308; DOI: 10.1136/ oem.44.5.292.

6. H. Wennborg, J. P. Bonde, M. Stenbeck and J. Olsen, Adverse reproduction outcomes among employees in biomedical research laboratories, Scand. J. Work Env. Hea. 28 (2002) 5-11.

7. M. L. Lindbohm, H. T. Taskinen, M. Sallman and K. Hemminki, Spontaneous abortions among women exposed to organic solvents, Am. J. Indust. Med. 17 (2007) 449-463; DOI: 10.1002/ajim. 4700170404 .

8. H. Wennborg, B. Lennart, V. Harri and A. Gösta, Pregnancy outcome of personnel in Swedish biomedical research laboratories, J. Occup. Environ. Med. 42 (2000) 438-446.

9. P. Kristensen, B. Hilt, K. Svendsen and T. K. Grimsrud, Incidence of lymphohaematopoietic cancer at university laboratory: a cluster investigation, Eur. J. Epidemiol. 23 (2008) 11-15; DOI: 10.1007/ s10654-007-9203-5.

10. P. Y. Khashaba, S. R. El-Shabouri, K. M. Emara and A. M. Mohamed, Analysis of some antifungal drugs by spectrophotometric and spectrofluorimetric methods in different pharmaceutical dosage forms, J. Pharm. Biomed. Anal. 22 (2000) 363-376; DOI: 10.1016/S0731-7085(99)00280-0.

11. F. M. Salama, O. I. A. El-Sattar, N. M. El-Abasawy and M. M. Fuad, Spectrophotometric determination of some ACE inhibitors through charge transfer complexes, Al-Azhar J. Pharm. Sci. 27 (2001) 121-132.

12. N. Rahman, N. Anwar and M. Kashif, Application of $\pi$-acceptors to the spectrophotometric determination of lisinopril in commercial dosage forms, Farmaco 60 (2005) 605-611; DOI: 10.1016/ j.farmac. 2005.04.011.

13. The United States Pharmacopeia 24, The National Formulary 19, United States Pharmacopeial Convention, Inc., Rockville 2000. 
I. A. Darwish et al:: A novel analytical approach for reducing the consumption of organic solvents in the charge transfer-based spectrophotometric analysis: Application in the analysis of certain antihypertensive drugs, Acta Pharm. 60 (2010) $493-501$.

14. L. I. Bebawy, N. M. El-Kousy, J. K. Saddik and M. Shokry, Spectrophotometric determination of fluoxetine and sertraline using chloranil, 2,3 dichloro-5,6-dicyano-benzoquinone and iodine, J. Pharm. Biomed. Anal. 21 (1999) 133-142; DOI: 10.1016/S0731-7085(99)00101-6.

15. A. Taha and G. Rücker, Utility of $\pi$-acceptors in alkaloid assay, Arch. Pharm. (Weinkeim) 310 (1977) 485-494.

16. H. P. Deppeler, Hydrochlorothiazide, in Analytical Profiles of Drug Substances (K. Florey, Ed.), Vol. 10, Academic Press, New York 1981, pp. 405-441.

$S A \check{Z} E T A K$

\section{Novi analitički pristup sa smanjenom potrošnjom organskih otapala u spektrofotometrijskoj analizi temeljenoj na prijenosu naboja: Primjena $\mathrm{u}$ analizi nekih antihipertenziva}

IBRAHIM A. DARWISH, ASHRAF M. MAHMOUD i ABDUL-RAHMAN A. AL-MAJED

U radu je opisan razvoj novog analitičkog pristupa koji 50 puta smanjuje potrošnju organskih otapala u spektrofotometrijskoj analizi na bazi prijenosa naboja (CT). Predložena metoda koristi ploče s 96 jažica za izvođenje analize. CT reakcije između elektron-donora i elektron-akceptora izvode se u jažicama s 200- $\mu \mathrm{L}$ organskog otapala. Promjene boje mjere se pomoću posebnog mikročitača za ploče s jažicama. Određeni su optimalni uvjeti za dva antihipertenzivna lijeka, ramipril (RML) i lizinopril (LSL) koji su upotrebljeni kao modelni spojevi za elektron-donorske analite, i 2,3-diklor-5,6-dicijano-1,4-benzokinon (DDQ) kao $\pi$-elektronski akceptor. U optimalnim uvjetima Beerov zakon je vrijedio u koncentracijskom području 6-100 i 6-60 $\mu \mathrm{g} \mathrm{mL}^{-1} \mathrm{za}$ RML, odnosno LSL. Granice detekcije bile su 0,97 i 1,1 $\mu \mathrm{g} \mathrm{mL}^{-1}$ za RML, odnosno LSL. Preciznost metode bila je zadovoljavajuća, a relativna standardna devijacija bila je manja od 1,1 \%. Predložena metoda uspješno je primijenjena za analizu doziranih farmaceutskih pripravaka koji sadrže ispitivane lijekove, uz dobru točnost i preciznost. Rezultati predložene metode usporedivi su s rezultatima poznatih metoda. Postupak opisan u ovom radu vrlo je praktičan: analitičari su manje izloženi toksičnim učincima organskih otapala, troškovi analize smanjeni su 50 puta, a također ju odlikuje visoka propusnost. Iako je postupak validiran za RML i LSL, ista metoda može se upotrijebiti za elektron-donirajući analit koji ulazi u CT reakciju.

Ključne riječi: reakcija prijenosa naboja, organsko otapalo, spektrofotometrija, ramipril, lizinopril

Department of Pharmaceutical Chemistry, College of Pharmacy, King Saud University, P.O. Box 2457, Riyadh 11451, Saudi Arabia 